\title{
An Attempt to Resurrect Engineering Education in Herat, Afghanistan
}

\author{
M. Saleh Keshawarz, Bahadur Khan Khpolwak \\ Associate Professor and Chairman of Civil and Environmental Engineering \\ University of Hartford, West Hartford, CT 06117, USA/Dean, \\ Faculty of Engineering, Herat University, Herat, Afghanistan
}

\begin{abstract}
Formal Engineering Education goes back to 1956 when engineering courses were offered as part of the Faculty of Science. However, it was not until 1996, when Engineering College started its operation as an independent college. The new college was built through the joint efforts of the Royal Government of Afghanistan and the United States Government. United States Agency for Development provided the funds for the infrastructure and faculty development.

During the Soviet occupation of Afghanistan in the early parts of 1980's, the college was stamped as an American institution and was targeted for elimination and was finally was shut down in 1984. By that time, a large number of the professors had migrated to foreign countries.

In 1984, a small group of these professors through funds provided by USAID, established a construction-related program in Peshawar, Pakistan, which lasted until USAID funds dried up in 1994.

Coordination of Humanitarian Assistance, CHA an Afghan non-governmental organization (NGO), with assistance provided by the then Governor of Herat, Ismael Khan, managed to rescue the program and transfer it to Herat, on the western side of Afghanistan. At the beginning the college was admitting both male and female, however, with the coming of Taliban to power, admission of female was suspended.

The college uses the same curriculum that was in place in Kabul University during 70's.

This paper reviews the efforts to resurrect the college and provides recommendation to modernize its curriculum as it relates to present Afghan situation. This is especially important in view of the fact that there is a sever shortage of literature on the subject.
\end{abstract}




\section{Background}

Twenty-three years of devastating war in Afghanistan destroyed the mediocre educational infrastructure that existed before the war. Faculty of Engineering in Kabul which was following a standard American type engineering curriculum was no exception.

The Faculty of Engineering in Kabul was established as part of the Faculty of Science in 1956. At the end of 1959, the first group of graduates received their Bachelor of Science degree from the Faculty of Engineering.

Through a contract with the United States Agency for International Development and Royal Government of Afghanistan, the University of Wyoming assumed the responsibility for guiding the new Faculty. The University of Wyoming supplied the staff members and equipment and established a four year "general" engineering program.

In 1958, a joint faculty of Engineering and Agriculture came into being, separate from Faculty of Science, and was located in temporary quarters.

In 1963, the Faculty of Engineering was separated from the Faculty of Agriculture, and at approximately the same time a new team, the United States Engineering Team (USET), took over from the University of Wyoming the responsibility for assisting and guiding the University. USET was the agency in Kabul charged with operational responsibility by a consortium known as the Kabul Afghan-American Program. It was comprised of the Education Development Center, Newton, MA, along with eleven American institutions; namely, Carnegie-Mellon University, Georgia Institute of Technology, Illinois Institute of Technology, Lehigh Un iversity, North Carolina State University at Raleigh, Purdue University, Rice University, Stevens Institute of Technology, University of Cincinnati, University of Notre Dame, and Washington University, (St. Louis).

Of great significance, also, was the move into new and permanent quarters at the end of the year 1963. This building was one of several newly constructed buildings on the new Kabul University Campus which were planned and built through the joint efforts of the Royal Government of Afghanistan and the united States Government. In 1970, a five-year curriculum was adopted. The five year curriculum was comprised of nine semester of academic work and six month practical training period.

The University of Nebraska Team through USAID came to Kabul University in 1974 until the communists took over the country in 1978 and one of the institutions they wanted to destroy was the Faculty of Engineering. They finally succeeded and in 1984 the Faculty of Engineering in Kabul was closed. By that time, a large number of professors of Faculty of Engineering migrated to foreign countries.

A small group of theses professors through funds provided by USAID established the Construction Related Training for Afghanistan (CRTA) in Peshawar, Pakistan in 1987. The program included a four-year bachelor level Construction Engineering Faculty, a two-year

Proceedings of the 2002 American Society for Engineering Education Annual Conference \& Exposition

Copyright (C) 2002, American Society for Engineering Education 
Construction Institute Program which trained construction supervisors and Assistant Engineers. All these programs were being funded by USAID.

The USAID aid was terminated in the early nineties and again a group of professor with the help of CHA and Ismael Khan the then Governor of Herat managed to rescue the program and move it to Herat, Afghanistan in 1995. The program is currently recognized by the ministry of Higher education and the degrees are conferred by Herat University. The Faculty is administered by CHA through funds provided by NOVIB.

Since the engineering program move to Herat in 1995 a total of 70 civil engineers have been graduated with majority of them having been gainfully employed. Table 1.1 shows enrollment data for the Faculty of Engineering in Herat since 1995.

Table 1.1: Enrollment data for Faculty of Engineering, Herat ${ }^{*}$

\begin{tabular}{|c|c|c||}
\hline \hline Year & Number Enrolled & Number Graduated \\
\hline 1995 & 50 & - \\
\hline 1996 & 35 & - \\
\hline 1997 & 45 & - \\
\hline 1998 & 59 & 22 \\
\hline 1999 & 66 & 23 \\
\hline 2000 & 73 & 24 (projected) \\
\hline 2001 & 92 & \\
\hline 2002 & & \\
\hline Total & & \\
\hline
\end{tabular}

* Source: Brief Introduction of CRTA by Engr. Bahadur Khan Khpolwak

As is evident from Table 1.1, there has been a steady increase in the number of students enrolled in the program. At the beginning the majority of students belonged to the Herat region, but as word spread about the success of the Faculty and its program, the number of out of town students increased substantially, surpassing the number of from Herat City.

There are students who have returned from Iran and Pakistan to attend the Faculty. This is an indication that the concept of "education for repatriation" is beginning to work. I spoke to two such students, one who went to Herat from Peshawar in search of a better education in his own country and another originally from Herat who finished high school in Iran and returned to Herat to attend the Engineering Faculty. He graduated last year and is working for CHA in its Ghor project.

Civil Engineering has become the second most popular major in Herat University after medicine. The level of salary for civil engineers is much higher compared to other fields. As and example, 
the typical salary for a government employee is about $\$ 15$ per month, while an engineer can easily make $\$ 150$ per month working for an NGO.

\section{Crriculum}

The faculty of Engineering in Herat is following the same curriculum that was designed for the Faculty of Engineering in Kabul in 1972. The only difference is the addition of some nontechnical subjects and offering of a five-year program in four years.

The ministry of Higher Education in Afghanistan recognizes the program and the President of Herat University signs on the diplomas. The curriculum in its current form is too heavy and some courses are not offered in the right sequence. In order to alleviate the problem, it is proposed to combine some courses, eliminate some, and move some to different se mesters.

\section{First Semester}

No change is proposed in the first semester.

\section{Second Semester}

In the second semester, statics is moved to third semester and Surveying II is moved to second Semester. The rational being that students need some calculus in order to understand some concepts in Statics and therefore it is moved to this semester where Math III is offered. Surveying II on the other hand, does not need any advanced math and therefore, it is moved to the Second Semester.

\section{Third Semester}

Strength of Materials (SOM) and Dynamics are moved from the Third Semester to Fourth Semester. Again math prerequisite for these courses requires them to be offered after Math III which is offered in the third semester. Fluid Mechanics is proposed to be combined with Thermodynamics and offered as a one four-credit course in the fourth semester. Statics, Geology, and Computer are moved to this semester because of their lower level math requirements.

\section{Fourth Semester}

Physics III is suggested to be combined with EE I in a four credit hour course. Important topics relevant to civil engineering from Physics III should be included in EE I. Structures is moved from the fourth semester to fifth semester and so is Hydrology. Surveying II is moved to the second semester. And, as discussed above (third semester), SOM, Dynamics, and Thermo-Fluid (new course) are moved to this (fourth) semester.

\section{Fifth Semester}


Concrete I is moved to sixth semester and so is Hydraulics to accommodate the continuity of subject matters and distribution of courses through the curriculum. Credits associated with Hydraulics is reduced from 5 to 4 , because there is no justification to having 5 credits for this course. Geology is moved to the third semester. Structures and Hydrology are moved to this (fifth) semester.

\section{$\underline{\text { Sixth Semester }}$}

Concrete II is moved to the eighth semester, Computer is move to the third semester, and thermodynamics is combined with fluid mechanics a single course and offered in the fourth semester. Concrete I and Hydraulics are moved into the sixth semester.

\section{Seventh Semester}

No change is proposed. A rethinking of the practical training and its value should be undertaken by the Faculty. Instead of on semester long practical training, a series of short ones during brakes may be sufficient to give the students the flavor of how things work in the field.

\section{Eighth Semester}

Management is proposed to be eliminated from the list of required courses. However, if the faculty feels it is important, the course can be offered as technical elective on a need basis. Concrete II is moved from the sixth semester to this semester.

The proposed change will decrease the total number of credits from 165 to 155 and will streamlines the course offerings. These changes should be incorporated over a period of time starting from freshman and start implementing the changes. The Ministry of Higher education and University of Herat should be consulted closely. The ideal situation would be if the changes are also implemented in the Faculty of Engineering, Kabul University. 


\section{Herat University}

Faculty of Engineering

Existing Curriculum

Proposed Curriculum

\section{FIRST SEMESTER}

FIRST SEMESTER

$\begin{array}{ll}\text { Islamic Studies } & 2 \\ \text { Math I } & 4 \\ \text { Intro. To Engg. } & 3 \\ \text { Chemistry I } & 4 \\ \text { Drawing I } & 3 \\ \text { Surveying I } & 3 \\ \text { Language } & 4\end{array}$

Total

Islamic Studies 2

Math I 4

Intro. To Engg. 3

Chemistry I 4

Drawing I 3

Surveying I 3

Language 4

Total 23

\section{Second Semester}

Islamic Studies 2

Math II 4

Chemistry II 4

Physics I 4

Drawing II 3

Statics 3

Language 4

Total 24

Second Semester

Islamic Studies 2

Math II 4

Chemistry II 4

Physics I 4

Drawing II 3

Surveying II 4

Language 4

Total 25

\section{Third Semester}

Third Semester

Islamic Studie 2

Math III 4

Physics II 4

SOM 4

Fluid Mech. $\quad 4$

Language 4

Dynamics 3

Total 25

$\begin{array}{ll}\text { Islamic Studie } & 2 \\ \text { Math III } & 4 \\ \text { Physics II } & 4 \\ \text { Statics } & \mathbf{3} \\ \text { Geology } & \mathbf{3} \\ \text { Language } & 4 \\ \text { Computer } & \mathbf{3}\end{array}$

Total

23 
Fourth Semester

Islamic Studies

Math IV

Physics III

Structures

Surveying II

Language

Hydrology

Total

\section{Fifth Semester}

Islamic Studies

Math V

Soil Mech.

Concrete I

Geology

Hydraulics

EE I

Total

Sixth Semester

Concrete II

Computer

Water Supply

Engg. Highway

Tech Comm

Thermodynamics

Tech. Elective

Total

Seventh Semester

Practical Training

Eighth Semester

Management

Project Design

Sanitary Engg.

Foundation Engg. 4

Tech. Elective 3

Engg. Economy 3

Total

Total Credits:
Fourth Semester

Islamic Studies 2

Math IV 4

SOM

Thermo-Fluid 4

Language 4

Dynamics 3

Total 21

Fifth Semester

Islamic Studies 2

Math V 4

Soil Mech. $\quad 4$

Structures $\quad 4$

Hydrology $\quad 3$

EE I

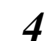

Total

21

Sixth Semester

\begin{tabular}{|c|c|}
\hline Concrete I & 4 \\
\hline Water Supply & 4 \\
\hline Engg. Highway & 4 \\
\hline Tech. Comm. & 2 \\
\hline Hydraulics & 4 \\
\hline
\end{tabular}

Total 21

Seventh Semester Practical Training

Eighth Semester

$\begin{array}{ll}\text { Concrete II } & \mathbf{4} \\ \text { Project Design } & 3 \\ \text { Sanitary Engg. } & 4 \\ \text { Foundation Engg. } & 4 \\ \text { Tech. Elective } & 3 \\ \text { Engg. Economy } & 3 \\ & \\ \text { Total } & \mathbf{2 1} \\ \text { Total Credits } & 155\end{array}$




\section{Teachers}

The Faculty relies on full-time as well as adjuncts to teach the classes. Table 3.1 depicts full time teaching staff along with their educational background.

Tabel 3.1: Full-time Teachers, Faculty of Engineering, University of Herat

\begin{tabular}{|c|c|c|c|c||}
\hline Name & B.S. & Master & Ph.D. & Admin. Resp. \\
\hline $\begin{array}{c}\text { Mohammad } \\
\text { Shah Ahmadzai }\end{array}$ & $\begin{array}{c}\text { EE, NC State } \\
\text { University } \\
\text { USA }\end{array}$ & $\begin{array}{c}\text { Applied Math } \\
\text { Purdue } \\
\text { University, USA }\end{array}$ & N/A & None \\
\hline $\begin{array}{c}\text { Qaseem } \\
\text { Mahammad }\end{array}$ & $\begin{array}{c}\text { CE, Faculty Of } \\
\text { Engineering, } \\
\text { Kabul University }\end{array}$ & N/A & N/A & Assistant Dean \\
\hline Nasir Ali & $\begin{array}{c}\text { EE, Faculty Of } \\
\text { Engineering, } \\
\text { Kabul University }\end{array}$ & N/A & N/A & $\begin{array}{c}\text { Academic } \\
\text { Manager }\end{array}$ \\
\hline $\begin{array}{c}\text { Mohammad } \\
\text { Akbar }\end{array}$ & $\begin{array}{c}\text { CE, CRTA } \\
\text { Peshawar }\end{array}$ & N/A & N/A & None \\
\hline $\begin{array}{c}\text { Abdul Wahid } \\
\text { Omar }\end{array}$ & $\begin{array}{c}\text { CE, CRTA } \\
\text { Peshawar }\end{array}$ & N/A & N/A & None \\
\hline \hline
\end{tabular}

One professor has a Masters degree and the rest are Bachelor level. Despite the level of education, they seem to be successful teachers and in command of their subject matter.

Teaching load distribution needs close attention. Load distribution should be according to the expertise, experience, and equity. Any new course assignment to a teacher should be looked at very carefully so that the teacher is not overloaded. Given the small size of the Faculty, all qualified professional staff, including the Dean should participate in teaching.

Two additional experienced professors are hired effective next semester. This should result in a better load distribution and ensure the integrity of the program if some teachers decide to leave the Faculty.

3.1 Language of Instruction: It is extremely important that the teaching is done in English using standard engineering textbooks. It will prepare the graduates for an environment where most of the technical communication is done in English.

3.2 Reward System for Teachers: To reward teachers participation in the betterment of the Faculty, the annual salary raises should somehow be related to at least three areas of: effective teaching, service to the Faculty, and scholarly work. Teaching can be evaluated on the basis of student evaluation, peer evaluation, improvements in teaching style, writing teaching supplements for a course, and other similar activities. 
Service to the Faculty can be judged based on the willingness and participation of teachers in the improvement of the Faculty both in the academic areas as well as improving the image of the Faculty. Helping in the preparation of proposal for funds to improve the Faculty can be included in this category. Mentoring of younger teachers is another aspect that can be counted as service.

Scholarly work can be assessed based on the teachers' own effort in his/her professional development in the form of consulting and publications. Given the wealth of data that have been generated by all the domestic and international NGOs in the past fifteen years and in the future, it is not very difficult to come up with short research papers reflecting the compilation and interpretation of those data. As an example, by compiling and interpreting the data from all the shallow and deep wells that are installed in various parts of the country, one can write a paper on the status of groundwater in different regions of Afghanistan. This type of scholarly work will also help the teachers in their future academic promotions through the University system.

\section{IV.Students}

Educational institutions revolve around students. Herat Faculty of Engineering is the second most popular faculty in Herat University. It attracts students not only from Herat itself but from other provinces as well. It even attracts students from among the refugee population in Iran and Pakistan, an indication of "repatriation for education" at work. There are 169 students enrolled in the program. There are 90 freshman, 33 sophomore, 22 juniors, and 24 seniors. About 78 students come from outside Herat City. These students are housed in crowded dorm rooms belonging to the University. CHA along with one Herat City businessman pay for food items. Table 4.1 shows the home province for these students.

It is a diverse group of students coming from all parts of Afghanistan. They live together in harmony in the dorms and they get along well with each other in their classrooms. Having educational programs like this will certainly take the young generation away from the frontlines and bring them to the educational institutions.

The number of students entering the Faculty increases steadily. A senior class of 24 and a freshmen class of 90 (keeping the attrition rate in mind) is a clear indication of the popularity of the program. There are several factors contributing to the larger class each year:

a. Following a standard curriculum.

b. Using standard textbooks (mostly American) for teaching engineering subjects. This will prepare them to function well in an environment where most of the communication require a working knowledge of English

c. Herat Faculty of Engineering through CHA's effort has been successful in attracting a group of teachers with sufficient background to deliver education leading to a BSCE degree.

Graduates of the Faculty have been successfully employed by different organizations. 
Table 4.1: List of students based on their province of origin ${ }^{*}$

\begin{tabular}{|c|c|c|c|c|}
\hline Year & Province & $\begin{array}{l}\text { Number of } \\
\text { Commuters }\end{array}$ & $\begin{array}{c}\text { Number of } \\
\text { Boarding }\end{array}$ & Total \\
\hline \multirow{4}{*}{ Seniors } & Herat & 17 & 2 & 19 \\
\hline & Kabul & & 2 & 2 \\
\hline & Wardak & & 3 & 3 \\
\hline & Total & 17 & 7 & 24 \\
\hline \multirow{9}{*}{ Juniors } & Herat & 11 & 3 & 14 \\
\hline & Farah & & 1 & 1 \\
\hline & Samangan & & 1 & 1 \\
\hline & Wardak & & 1 & 1 \\
\hline & Laghman & & 1 & 1 \\
\hline & Paktia & & 1 & 1 \\
\hline & Logar & & 2 & 2 \\
\hline & Ghazni & & 1 & 1 \\
\hline & Total & 11 & 11 & 22 \\
\hline \multirow{5}{*}{$\begin{array}{l}\text { Sophomo } \\
\text { re }\end{array}$} & Herat & 16 & 12 & 28 \\
\hline & Farah & & 3 & 3 \\
\hline & Wardak & & 1 & 1 \\
\hline & Laghman & 1 & & 1 \\
\hline & Total & 17 & 17 & 34 \\
\hline \multirow{14}{*}{ Freshman } & Herat & 45 & 10 & 55 \\
\hline & Farah & & 4 & 4 \\
\hline & Wardak & & 12 & 12 \\
\hline & Khost & & 1 & 1 \\
\hline & Ghor & & 1 & 1 \\
\hline & Logar & & 1 & 1 \\
\hline & Kapisa & & 1 & 1 \\
\hline & Paktia & & 1 & 1 \\
\hline & Kabul & 1 & 6 & 7 \\
\hline & Zabul & & 2 & 2 \\
\hline & Ghazni & & 3 & 3 \\
\hline & Badghis & & 1 & 1 \\
\hline & Badakhshan & & 1 & 1 \\
\hline & Total & 46 & 44 & 90 \\
\hline & Grand Total & 91 & 78 & 169 \\
\hline
\end{tabular}

*Source: CHA, Herat Regional Office, Education Sector 
A follow up study of the graduates of the Faculty for the past three years is shown in Table 4.2 .

Table 4.2: Follow-up study of civil engineering graduates from Faculty of Engineering, Herat $^{*}$

\begin{tabular}{|c|l|c|c|c||}
\hline \multirow{2}{*}{ Number } & \multirow{2}{*}{ Organization } & \multicolumn{3}{|c|}{ Year } \\
\cline { 2 - 4 } & & 1998 & 1999 & 2000 \\
\cline { 2 - 4 } & & 22 & 25 & 23 \\
\hline 1 & CHA & 2 & 2 & 12 \\
\hline 2 & DACAAR & & 1 & 1 \\
\hline 3 & OI & & & 1 \\
\hline 4 & WHO & & 1 & \\
\hline 5 & PAMA & 1 & 2 & \\
\hline 6 & Municipality & 1 & & \\
\hline 7 & Construction Corporation & 1 & & 1 \\
\hline 8 & Habitat & 1 & & \\
\hline 9 & AREA & 2 & & \\
\hline 10 & Swedish Committee & & & 1 \\
\hline 11 & OXFAM & & & 1 \\
\hline 12 & CARE & & & 1 \\
\hline 13 & Sistan Construction Corporation & 1 & & 1 \\
\hline 14 & Recol Corporation & & & \\
\hline 15 & Lajnatadaawa & & & 1 \\
\hline 16 & Rural Development & & 1 & \\
\hline 17 & Development for Afghanistan & & 2 & \\
\hline 18 & ARF & & 2 & 2 \\
\hline 19 & Private Work & & & \\
\hline 20 & Jobless & & & \\
\hline 21 & Unknown & & & \\
\hline 22 & Left the Country & & & \\
\hline & Total Graduates & & \\
\hline \hline Source & CHA & & \\
\hline
\end{tabular}

*Source: CHA

Graduates of the Faculty function well in developmental and emergency relief environment. I interviewed a group of young engineers graduated from this program while attending a human right seminar in Herat. I had never met a group of engineers so dedicated and enthusiastic about their work. They were stationed in Ghor, which is hit by two consecutive years of drought. Ghor is one of the more inaccessible and inhospitable terrains in Afghanistan. The young engineers were telling me of having to dig shallow holes covering them with flat stone to protect themselves from wild animals at night.

One of the young engineers had finished his high school in Iran and had come back to Herat to finish his engineering education in the Faculty. He stayed back after graduation and was hired by $\mathrm{CHA}$. He was telling me that if the educational opportunities such as the one he went through

Proceedings of the 2002 American Society for Engineering Education Annual Conference \& Exposition

Copyright $\odot$ (2002, American Society for Engineering Education 
were widely available inside Afghanistan, many families would rather come back and stay in Afghanistan than stay in Iran. It was an uplifting experience for me to talk to this group of young engineers. It reminded me of real civil engineering work.

\section{Resources and Facilities}

The faculty of engineering in Herat is located within the CHA complex in Herat. Space is certainly a problem that is going to get worst as the number of students is increased in the Faculty. The CHA compound has three buildings two of which are given to the Engineering Faculty.

The main engineering building is a two-story structure with a basement The construction material lab, the chemistry lab, and the library are located in the basement; the classrooms in the first floor and the offices are located in the second floor.

Herat University under its master plan has purchase about 140 jarib (56 acres) of land put aside for the construction of new university buildings. The Faculty of Engineering has its share of the land. With the availability of funds, it is essential to build a new building for the Faculty so that the space problem facing the faculty is resolved.

\subsection{Library}

The library is located in a very small room in the basement. It is in no way adequate for an engineering faculty. Efforts should be made to increase the number of holdings and a new space should be dedicated so that students can use it more effectively.

\subsection{Computers}

Perhaps one of the highest priority in the Faculty must be the establishment of a computer lab for students and providing computers to the teaching staff. The acquisition of at least twenty computers will be enough to establish a computer lab. Students will use them for computation, drafting, and writing laboratory reports. One of the young teachers could be trained to teach computer-aided design (CAD) to the students.

\subsection{Textbooks}

The Faculty is severely suffering from the shortage of textbooks. Existing edition of textbooks are old and outdated. One text is shared by several students which severely hamper their ability to prepare for their classes. Several alternatives could be followed to alleviate the problem.

As a first alternative, it is necessary to contact American publishers for their South Asian prints. I have identified three publishers in India who work on reprinting American books for Asia:

- Vikas Publishing house, New Delhi, representing PWS-Thompson Publications

- Khana Publications

Proceedings of the 2002 American Society for Engineering Education Annual Conference \& Exposition

Copyright $\odot$ 2002, American Society for Engineering Education 
- Tata-McGraw Hill publications

As a second alternative, American publishers should be approached to donate the previous editions of their books for this cause or to sell them at a discount. A third alternative would be to ask the publishers for rights to reprint their books here at CHA's facilities. A fourth alternative would be to collect books from individual professors and send them to Herat. This last step I have been pursuing for a number of years and have collected some books that will be sent if other alternatives do not work.

\section{Support Staff}

The administrative structure of the Faculty consists of the Dean, the Assistant Dean, the Academic Manager, a full time technician, and a librarian. Staffing seems to be adequate for a Faculty of this size.

\section{Professional Development}

Currently there are no formal professional development opportunities available for the teaching staff. This has become a major source of frustration for the teaching staff especially the junior professors. They look at their careers as a dead end one without any educational progress. If something is not done soon, there will be a danger of losing most of the junior and may be some senior professors as well.

Several strategies can be followed to improve professional development in the faculty:

- Individual professional development, in which the professor pursues consulting, research, and writing books. These activities should be encouraged and rewarded by the Faculty. Some teachers are already involved in theses types of activities. Others should be encouraged to do so.

- CHA with the help of a funding agency should form a collaborative alliance with one or more Universities in the US to help it in terms of professional development, curriculum, and visiting professors. As a first step, the possibility of alliance should be explored with the University of Hartford in Connecticut, USA.

- Contact with Universities in the region should be established to see if there are opportunities for higher education in those countries for teachers and top graduates of Herat Faculty of Engineering. Sending teachers and some of the top students to those institutions for Masters degree will ensure a continued supply of teachers with at least a master's degree.

- United States Agency for International Development (USAID), British Council, and Canadian Development Agency should be approached to provide these opportunities for the Teachers. USAID has traditionally been a supporter of the Faculty of Engineering. They may still be interested in continuing the support. 


\section{Other training activities}

There are at least two other training activities which are directly related to the Faculty of Engineering in Herat, the Refresher Courses and the Galaxy Training Center.

\subsection{Refreshers and Professional Development Program:}

The objective the short term refresher and professional development course is to keep Afghan engineers abreast of the latest development in their field by providing short term technical refresher and professional courses. Topics covered so far include Engineering Management, Design and Construction of Roads and Bridges, Reinforced Concrete, Water Supply and Sanitary Engineering and Foundation Engineering. These refresher courses are extremely important and are very well attended and popular among Afghan Engineers. So far two sessions of refresher courses are given in Herat City and one in Kabul. Each refresher course is for duration of one month in which the professors cover the relevant material in one of the national languages. This is particularly helpful to those engineers who do not have any English skills. A total of 226 students have gone through these refresher courses and they ask for more.

In future, it is suggested the management of these course be more centralized and the course should be offered at a time not to conflict with regular teaching activities of the Engineering Faculty. They should be carefully offered in places where they are needed the most. Revenues from these courses should benefit the Faculty of Engineering in terms of more equipment for the Faculty and students.

\subsection{Galaxy Training Centers:}

The first Galaxy Training Center was established in Herat in 1993 for both male and female. Courses in the training center are devoted to providing opportunities for Afghan students to learn office skills such as English, Computers, Typing, and also prepatory sciences course to supplement high school education Because of the success of the program and demand, other centers have been opened in Kandahar, and Peshawar. Soon, there will be one opened in Kabul and another in Mazar. There are a total of 2731 students receiving training in these centers. Table 8.1 reflects the number of students in each center and in each field.

Female students make up the majority in the Peshawar Center. Other centers will start a women section as soon as the government in Afghanistan would agree. The quality of education in theses center are excellent judging from direct conversation with students in Herat and Peshawar.

Some dramatic real success stories: Rameen who was a street vendor selling fruits started the program on a part time basis and now he is working as administrative Manger with Medicine Sans Frontiers (MSF). Jaafar who was selling potato on the street corner is working with an NGO making a good living. Basir who was a peon in the office started with the literacy program and now is a teacher in the center and also work with an NGO. 
Table 8.1: Number of students in different fields at Galaxy Training Centers

\begin{tabular}{|c|c|c|c|c|c|c|c|c|c|c|c|c|c|c|}
\hline \multirow{3}{*}{$\begin{array}{l}\text { Locatio } \\
n\end{array}$} & \multicolumn{14}{|c|}{ Number of Students } \\
\hline & \multicolumn{2}{|c|}{ English } & \multicolumn{2}{|c|}{$\begin{array}{l}\text { Compute } \\
\mathrm{r}\end{array}$} & \multicolumn{2}{|c|}{ Painting } & \multicolumn{2}{|c|}{$\begin{array}{l}\text { Calligrap } \\
\text { hy }\end{array}$} & \multicolumn{2}{|c|}{ Science } & \multicolumn{2}{|c|}{ Arabic } & \multicolumn{2}{|c|}{ Literacy } \\
\hline & $\mathrm{M}$ & $\mathrm{F}$ & $\mathrm{M}$ & $\mathrm{F}$ & $\mathrm{M}$ & $\mathrm{F}$ & M & $\mathrm{F}$ & $\mathrm{M}$ & $\mathrm{F}$ & $\mathrm{M}$ & $\mathrm{F}$ & $\mathrm{M}$ & $\mathrm{F}$ \\
\hline $\begin{array}{l}\text { Peshaw } \\
\text { ar }\end{array}$ & 70 & \begin{tabular}{|l|}
21 \\
5
\end{tabular} & 35 & 41 & 8 & 14 & 6 & 12 & 20 & 14 & 0 & 0 & 0 & 0 \\
\hline Herat & $\begin{array}{l}106 \\
0\end{array}$ & 0 & 57 & 0 & 18 & 0 & 21 & 0 & 59 & 0 & 32 & 0 & 28 & 0 \\
\hline $\begin{array}{l}\text { Kandah } \\
\text { ar }\end{array}$ & 816 & 0 & 41 & 0 & 0 & 0 & 54 & 0 & 0 & 0 & 42 & 0 & 68 & 0 \\
\hline Total & $\begin{array}{l}194 \\
6\end{array}$ & $\begin{array}{l}21 \\
5\end{array}$ & $\begin{array}{l}13 \\
3\end{array}$ & 41 & 26 & 14 & 81 & 12 & 79 & 14 & 74 & & 96 & 0 \\
\hline
\end{tabular}

*Source: CHA

The quality of spoken English is way above any thing I have seen in any Afghan e ducational institution, even before the war. The students are extremely motivated and very optimistic about their future. Teachers are well qualified. Some of them have published books in their areas of expertise. The Herat Center needs equipment and library with English books and magazines.

\section{Summary :}

CHA and a group of Professors from CRTA Peshawar and others under extremely difficult conditions and with support from Ismael Khan the previous Governor of Herat and financial support from NOVIB have managed to establish the Faculty of Engineering education in Herat, Afghanistan.

The engineering program in Herat, which is built on the same model as the old USAID, funded Faculty of Engineering program in Kabul is successfully in place and attracting students from far corners of Afghanistan. It is recognized by the University of Herat and the Ministry of Higher Education. It is clearly, albeit in a small scale, turning the young Afghans away from the war fronts and refugee life in the neighboring countries toward education.

CHA's other educational programs are also very successful in educating young Afghan men and women (women only in Peshawar) to develop basic office skills through providing opportunities in English courses and computers.

A summary review of the Faculty of Engineering in Herat and other related CHA training programs is presented here.

- Curriculum: The curriculum contains too many courses and a few of them are offered out of sequence. It is proposed to reduce the total number of credits from 165 to 155 by eliminating and combining courses. A more streamlined course offering sequence is also presented. 
- Students: Enrollment is high. The concept of "Repatriation for Education" is beginning to work. Students are from diverse backgrounds and motivated. Their high school preparation in not enough. The dorm rooms are very crowded. Employability after graduation is very high.

- Teachers: They are qualified and dedicated. They need professional development and a structured compensation formula for new hires and annual raises. Load distribution among the faculty needs to be reevaluated. It is proposed that the annual raises be tied to three criteria: teaching, service, and scholarly work.

- Facilities: Existing labs are, in general, adequate. There is an urgent need to establish a Computer Laboratory, fix and move the tensile testing machine from Peshawar to Herat. The library needs to be expanded.

- Textbooks: Textbooks are old, outdated, and not enough. Acquiring South Asian Prints of American books, previous editions of the books, reprints of American books, and collection from individual professors in the US are some of the strategies that need to be followed.

- Professional Development: Encourage individual professional development in the form of consulting, writing papers, and writing books of supplement to books; initiate contact between the Faculty and foreign institutions.

\section{Recommendations:}

1. Faculty of Engineering should seriously start looking at the proposed curriculum. Since there is no change in the first semester course offerings, the new curriculum can be implemented as soon as the next academic year. Provided that the Faculty of Engineering teachers and Herat University will go along with the proposed changes.

2. Teachers' salaries and annual raises should be structured.

3. CHA should approach USAID and see if it can start its traditional role of supporting the engineering program in Afghanistan, not only in Herat, but in other parts of Afghanistan as well. USAID in the past has helped with the infrastructure. It will not hurt to ask them about financing a building for the faculty of Engineering in Herat.

4. CHA with the help of a funding agency should form a collaborative alliance with one or more Universities in the US to help it in terms of faculty development, curriculum, and visiting professors. As a first step, the possibility of alliance should be explored with the University of Hartford in Connecticut, USA as soon as possible. 
5. Contact with Universities in the region should be established to see if there are opportunities for higher education in those countries for top graduate of Herat Faculty of Engineering. Sending teachers and some of the top students to those institutions for Masters degree will ensure a constant supply of teachers with at least a master degree.

6. CHA should aggressively publicize its activities in educational areas. Some people, especially in the US think that the only thing that is going on in Afghanistan is war. By doing so, more organizations will come forward to help.

7. Establishing a computer lab and providing textbooks should be the top priority. Proposals to that effect should be prepared and submitted to funding agencies immediately. The strategy outlined in the body of the report on how to get textbooks should be tried as soon as possible.

8. Faculty of Engineering, the Galaxy Training Centers in Peshawar for women and the ones in Herat and Kandahar, and the Science Laboratory should be highlighted on the web site. Interviews with "dramatic successes" should be posted on the web. Participation of women should be highlighted.

\section{Biographies}

M. SALEH KESHAWARZ

M. Saleh Keshawarz is an Associate Professor and Chairman of the Civil and Environmental Engineering Department at the University of Hartford. He is a Registered Professional Engineer in the State of Connecticut. He received his BSCE from Kabul University in Afghanistan, his M. Engineering in Civil Engineering from Tennessee State University in Nashville, Tennessee, and His Ph.D. in Civil Engineering from the University of Oklahoma in Norman Oklahoma.

\section{BAHADUR KHAN}

Bahadur Khan is the Dean of Faculty Of Engineering at Herat University. He received his BSCE from Kabul University in Afghanistan. He was instrumental in moving the Faculty of Engineering from Peshawar, Pakistan to Herat, Afghanistan. 